\title{
COLLABORATIVE ECONOMY AND ITS AWARENESS IN VISEGRAD GROUP COUNTRIES AND WITHIN THE EUROPEAN UNION
}

\author{
Tünde Zita Kovács, University of Debrecen, Hungary, kovacs.tunde.zita@econ.unideb.hu \\ Forest David, University of Debrecen, Hungary, forestdavid5@gmail.com \\ Krisztián Kovács, University of Debrecen, Hungary, kovacs.krisztian@econ.unideb.hu \\ Péter Popovics, University of Debrecen, Hungary, popovics.peter@econ.unideb.hu \\ András Nábrádi, University of Debrecen, Hungary, nabradi.andras@econ.unideb.hu
}

\begin{abstract}
The explosion of platform based collaborative economy $(C E)$ into the tertiary sector has changed the balance of power of market. The purpose of the study aims at introducing the CE, with special regard to its varieties and definitions and its awareness in Visegrad Group (V4) countries and in EU. Article includes both primary and secondary research. The international literature review was carried among definitions of CE from the last 10 years' articles. It was found that there is no uniform definition of CE, and it also turned out that the scope of activities related to the concept is not uniformly organized. This article is also focuses on the economic markets of the (V4) countries CE from supply and demand-side aspects by analysing EU database with SPSS software. The estimation of CE services reveals a more positive picture among Polish and Czech residents, whereas Slovak respondents are an average of EU-28. Despite the fact that Hungarian respondents are most familiar with the $C E$, they are the most conservative in with consideration. The most popular CE platforms are accommodation and transport services in V4 countries. To the best of our knowledge, the analysis of this topic has not been carried out.
\end{abstract}

Keywords: Collaborative Economy, Sharing Economy, Collaborative Consumption, Spreading of Collaborative Economy in V4, SPSS Analysis.

\section{INTRODUCTION}

Sharing, lending, and bartering, which are the basis of the collaborative economy, are as old as humanity, but its widespread adoption is only possible with the wide range use of the Internet (Belk, 2014). The dynamic development of the platform-based collaborative economy in the tertiary sector in recent years has profoundly reorganized power relations. It has been estimated that $\$ 23$ billion of venture capital has been invested in startups in this area since 2010, but its true size is difficult to estimate as most platform-based providers are privately owned (Wallenstein \& Shelat, 2017). The most significant changes have been made in passenger transport and accommodation, with names such as Uber, Didi Chuxing, Lyft or Airbnb. Airbnb is an American home rental platform launched in the fall of 2008, which combines demand with short-term real estate availability. Airbnb joined the Unicorn Club in the summer of 2011 with a current value of \$ 35 billion (January 2020) and is sixth in the ranking of the list of over 300 businesses (CBInsights, 2020). Uber, another celebrity face of the collaborative economy, was a member of the Unicorn family between 2013 and 2019, worth $\$ 72$ billion ( $2^{\text {nd }}$ place), but the primary issue of the company's shares ended on May 10, 2019 and began trading in the US. Stock Exchange (Feiner, 2019). The Uber's Chinese competitor, Didi Chuxing valued at $\$ 56$ billion, is the $3^{\text {rd }}$ most valuable Unicorn in the world, and since its foundation in 2012 has 18 venture capital investments, raising a total of $\$ 21$, 2 billion from 31 investors (Hurun Research Institute, 2019). Uber, Lyft and Didi Chuxing are ride-hailing platforms. Several factors have contributed to the spread of the collaborative economy, such as the explosive development of the above-mentioned Internet infrastructure, but also economic and social changes (PwC, 2015). However, consumer research at the BCG Henderson Institute clearly demonstrates that the economic situation, not the consumer attitude, is the driving force of the collaborative economy (Wallenstein \& Shelat, 2017). Beyond passenger transportation and accommodation, as the most popular platform-based collaborative economy services, it has spilled over into other areas, including fashion, energy, real estate, travel, transportation, finance, food and entertainment (Gansky, 2010). The areas of transformation where traditional services are too complicated, slow, cumbersome and bureaucratic are particularly affected. In 2016, 44, 8 million adult American citizens used the collaborative economy and is expected to reach 86, 5 million by 2021 (Miller, 2019). According to PwC's projections in the EU the $€ 28$ billion revenue of the collaborative economy in 2015 could reach $€ 570$ billion by 2025 (PwC, 2016).

Nonetheless, the collaborative economy is a largely under-researched area and relatively little is known about its true impact on the economy, society and the environment (OCU, 2016). The database of the European Commission Survey 2018, which measured the awareness of participants in transactions done within platforms 
supporting collaborative economy in the EU member states, will serve as source for this research, focusing on Visegrad Group (V4) countries (the Czech Republic, Hungary, Poland and Slovakia): The aim is also to statistically support the advantages and, at the same time, the barriers of their spread. The analysis is compared the data found in the V4 countries with the average of the EU-28. Cross-analyses and frequencies were analysed considering different background variables.

\section{METHODOLOGY}

This work consists on both primary and secondary approaches to the topic. The research questions centred on this peculiar new type of business model and clarified the definition of the collaborative economy. The article concentrated to clarify what unambiguous categories and sub-categories of the collaborative economy can or do exist. The international literature review was carried among definitions of classifications and grouping of Sharing Economy (SE) and Collaborative Consumption (CC) type models. The analysis were reviewed from the past 10 years' articles without the need for completeness. Finally, the authors of this study completed a demand-side and platform-driven business model elements based on literary processes and the author's own analysis, it was explored the components of the system, and then came up with definitions that can make a clear distinction among collaborative-economy businesses.

Based on this, authors conducted in-depth analyses of the EU and V4 countries using primary data from the available database. European Commission, Brussels (2018): Flash Eurobarometer 467 (The Use of the Collaborative Economy) ZA6937 Data file Version 1.0.0 was requested / received as a secondary research resource from the survey institute (European Commission, 2018), where 26.544 survey basic and derived data were analysed and processed with SPSS 25 software. The study was basically approached from two sides (Table 1): on one hand, it was analysed the demand side of the collaborative economy and, on the other hand, the supply side of service providers.

Table 1. Collaborative Economy Approaches

\begin{tabular}{|l|l|}
\hline \multicolumn{1}{|c|}{ Demand side (users) } & \multicolumn{1}{|c|}{ Supply side (providers) } \\
\hline $\begin{array}{l}\text { Proportion of users of services offered via } \\
\text { collaborative platforms }\end{array}$ & $\begin{array}{l}\text { Proportion of providers of services offered via } \\
\text { collaborative platforms }\end{array}$ \\
\hline Popularity of provided services & Popularity of provided services \\
\hline Advantages and disadvantages of provided services & Reasons for offering services \\
\hline Reason for not using services & $\begin{array}{l}\text { Main problems of service providers using } \\
\text { collaborative platforms }\end{array}$ \\
\hline
\end{tabular}

Source: Authors' own editing

The revealed relationships were confirmed by statistical analyses. During analysis it were used simple analytical / descriptive statistical methods, frequency analyses, crosstab analyses, chi-square test, and Fisher's exact test. Following analyses in the EU-28, author's analysis focused on the V4 countries. They have explored in detail the main links between the user and the provider side. The database surveyed had 4.001 respondents in the V4 member states, with an average of around 1.000 at EU level. In all countries, respondents answered by telephone. The database also contained background variables, one of which was used for analysis.

\section{BACKGROUND AND LITERATURE REVIEW}

The scientific literature does not seek to establish a common view regarding the nomenclature and definitions (Kumar, Lahiri, \& Dogan, 2018). Botsman \& Rogers (2010) prefer the use of collaborative economy rather than sharing economy. They propose that hyper-consumption, induced by the provision of loans, typical of the 20th Century, will be replaced by collaborative consumption, and its key drivers will be reputation and prestige. Dajnoki \& Héder (2017) and Héder, Szabó, \& Dajnoki (2018) also highlights the importance of the branding. The main features of hyper-consumption were advertisements, and they were characteristically based on ownership. In contrast, collaborative consumption will be typically community-focused with a sense of togetherness and belonging to the place where we live and share the rights of use (Botsman \& Rogers, 2010). The collaborative economy offers new opportunities for sustainability through the "holy trinity" of efficiency, consistency and sufficiency (Heinrichs, 2013).

As Schor \& Fitzmaurice (2015) highlights in his thesis, an activity can be considered sharing if it is self-defined as such and the press regards it determinative. It is for everybody to decide whether their activities are covered by the sharing economy collective term. Sharing economy activities fall into four broad categories: recirculation of 
goods, increased utilization of durable assets, exchange of services, and sharing of productive assets.

Sundararajan (2016) and Martin, Upham, \& Budd (2015) underline the significance of sharing on promising, cutting-edge P2P (peer-to-peer) marketplaces encouraging users to contact each other for the pursuit of economic activities. Sundarajan (2016) and Stephany (2015) analysed the shift in the consumption model, from ownership towards sharing, softening the necessity of the ownership of assets.

"The expression sharing economy is commonly used to indicate a wide range of digital commercial or non-profit platforms facilitating exchanges amongst a variety of players through a variety of interaction modalities ( $\mathrm{P} 2 \mathrm{P}$, peer-to-business (P2B), business-to-peer (B2P), and business-to business (B2B)), that all broadly enable consumption or productive activities leveraging capital assets (money, real estate property, equipment, cars, etc.) goods, skills, or just time (Codagnone, Biagi, \& Abadie, 2016, p. 22).

The European Commission defined collaborative economy as follows: "it ... refers to business models where activities are facilitated by collaborative platforms that create an open marketplace for the temporary usage of goods or services, often provided by individuals. The collaborative economy involves three categories of actors:

1. service providers who share assets, resources, time and/or skills - these can be private individuals offering services on an occasional basis ("peers") or service providers acting in their professional capacity ("professional service providers");

2. users of these;

3. and intermediaries that connect — via an online platform — providers with users and facilitate transactions between them ('collaborative platforms').

Collaborative economy transactions generally do not involve a change of ownership and can be carried out forprofit or not-for-profit." (European Commission, 2016)

Szegedi (2019) stated that sharing-based activities have four key features:

- $\quad$ the activity is webpage-, application- or online platform-based;

- $\quad$ allows for a P2P transaction;

- $\quad$ ensures temporary access to assets, services without transfer of ownership. This feature excludes the sale of second-hand goods and online platform-based transactions from the umbrella term of sharing economy;

- $\quad$ unexploited assets, services, skills or resources will be employed.

Summarizing, based on what has just been listed is that distinct authors/sources have highlighted varying essentials in the case of companies under the umbrella of sharing economy. In their definitions, we find similarities, differences and overlaps in the description of the models. Botsman \& Rogers (2010) emphasized collaborative consumption, Sundarajan (2016) and Martin et al. (2015) the novelty of the contact, Sundarajan (2016) and Stephany (2015) pointed sharing instead of owning, i.e. limiting the need for ownership. Codagnone et al. (2016) has highlighted commercial and not-for-profit platforms through the sharing of capital for consumption and production activities. Schor (2014) emphasized the reuse of goods, thereby increasing the use of fixed assets. Heinrichs (2013) notices the transactions of the new model in sustainability and environmental protection. Szegedi (2019) emphasizes p2p through applications, where interim financing and asset utilization can be improved. According to European Commission (2016), collaborative economy transactions generally do not involve change of ownership and can be carried out for-profit or not-for-profit.

\section{RESULTS/FINDINGS}

\section{Classification of Platform-Based Collaborative Economy}

The term collaborative economy (Kovács \& Nábrádi, 2020) is described as a demand-driven business model based on the Internet platform. The demand driven business model is defined as the economic activity created by digital marketplaces and technology companies to fulfil consumer demand via immediate access to goods and services through Internet platform (Jaconi, 2014). On digital marketplace product or service information is provided by multiple third parties, whereas transactions are processed by the marketplace operator (technology company). We can declared the business model is not only about renting, but about the re-use of unused assets through sales and the use of online marketplaces. The collaborative platform based economy (Figure 1) distinguishes between the concepts of Collaborative Consumption (CC) and Sharing Economy (SE), which it defines as follows:

CC - Demand-driven Internet platform based business model in which the service provider is a business and can operate in a redistribution market system or product service system. In a redistribution market system, the 
ownership of the good is transferred to the consumer after the transaction (sale), while the product service system allows only temporary access to the same good (leasing). Transactions can occur in B2B and B2P configurations. SE - Demand driven business platform based on an Internet platform where the service provider is a peer and can operate in a redistribution market system or product service system. In a redistribution market system, the ownership of the good is transferred to the consumer after the transaction (sale), while the product service system allows only temporary access to assets (renting). Transactions can occur in both P2P and P2B configurations

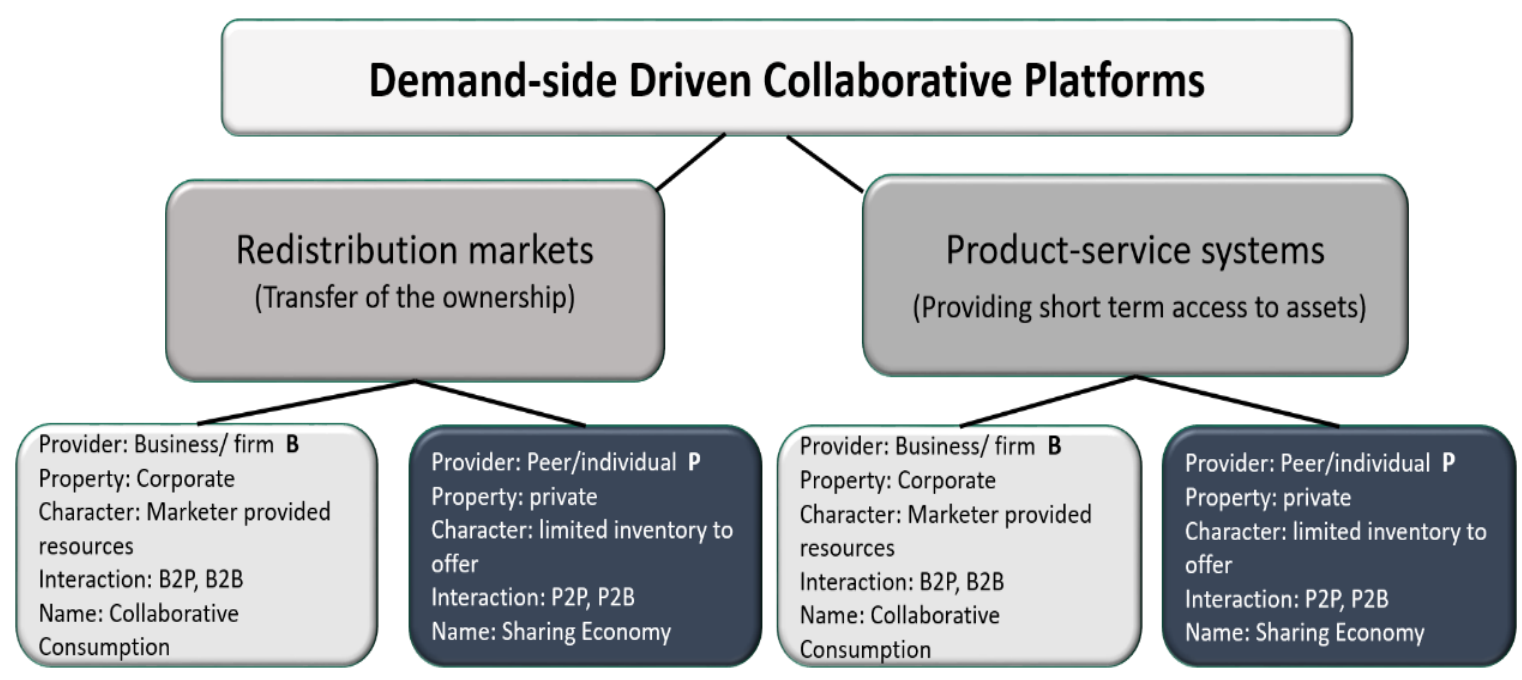

Figure 1. Classification of Demand-Side Driven Collaborative Platforms Source: (Kovács \& Nábrádi, 2020)

\section{Collaborative Platform Market in V4 Countries}

The open-access database of the European Commission, Brussels (2018) was analysed and processed using SPSS 25 statistical software. The results of the processing are detailed below. Looking at the consumer and / or service activities of collaborative platforms by country, a fairly uniform picture emerges, with the majority of member states having between $75 \%$ and $85 \%$ of those who do not apply this economic trend either in terms of users or service providers (Figure 2).

Among the 4 member states surveyed, the proportion of non-users in Hungary and Slovakia is slightly lower, but still 70\%. In the Czech Republic, almost 18\% of respondents said they had already used a collaborative platform, whether as a user or a service provider, or both. The users had the highest percentage (13,9\%). 1, 2\% of the respondents are present on the collaborative platform as user and service provider.

The highest proportion of users is in Slovakia $(26,8 \%)$, which is almost twice the proportion of users in the Czech Republic or Poland $(15 \%)$. Most service providers operating on social platforms are also found in Slovakia (2, $3 \%)$, but this rate is still very low.

The share of Polish service providers is one quarter of that of Slovakia, even less than 1\%, but the situation is similar in Hungary $(0,7 \%)$. Among users of collaborative platforms, in V4 countries, the share of users on these platforms is about $20 \%$, both users and service providers. 


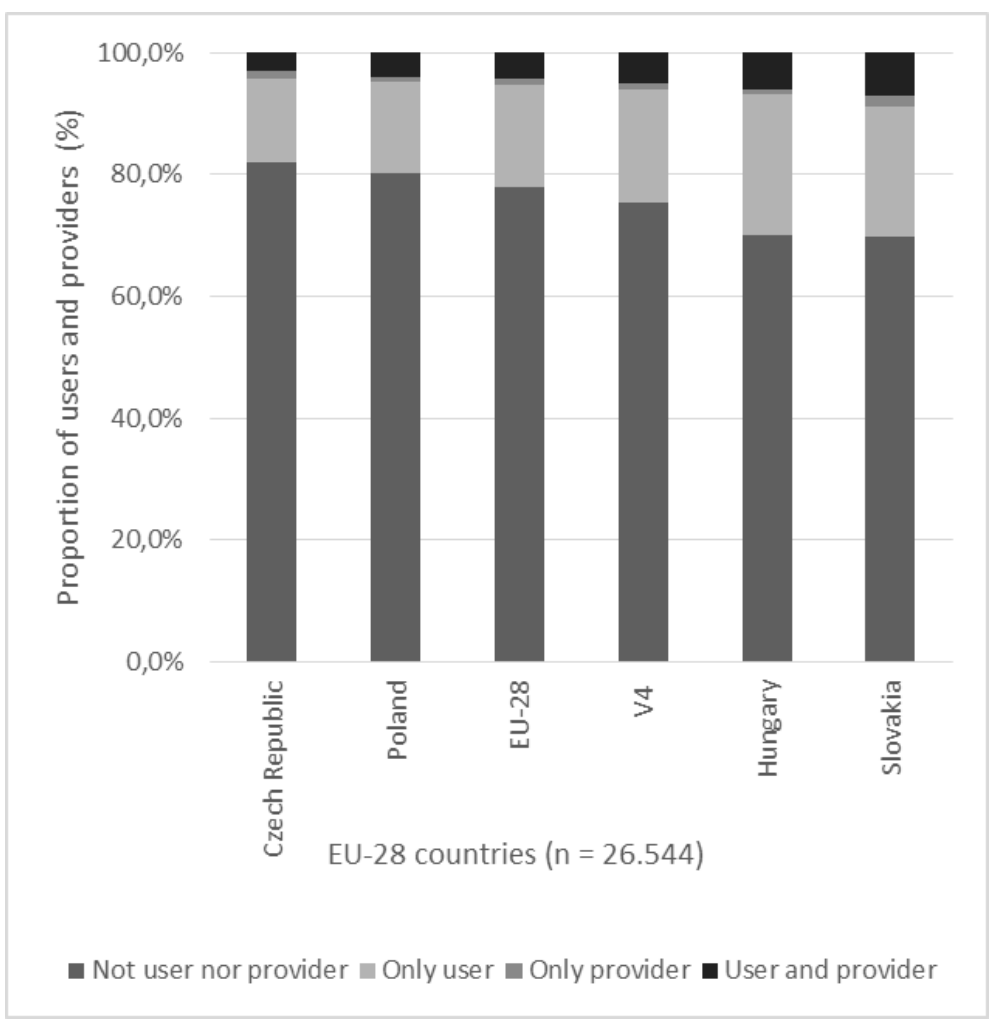

Figure 2. Proportion of Users and Providers of Services Offered via Collaborative Platforms by Country Source: Authors' own editing

\section{The Demand Side of Collaborative Economy Platforms}

When looking at collaborative economy platforms from a consumer perspective, the share of service users is the lowest in the Czech Republic (17\%) and the highest in Hungary (29,3\%) if the frequency of use is not considered relevant (Figure 3). Slovak and Hungarian users are 50\% higher than Czech and Polish users. The proportion of one-time users in Hungary is extremely high $(15,4 \%)$ compared to other V4 countries, while the proportion of occasional and regular users is higher in Slovakia. The proportion of users not using the platforms of the collaborative economy is $17 \%$ higher in the Czech Republic (83\%) than in Hungary (70,7\%) or Slovakia (71, $1 \%)$, but higher than the EU-28 average $(78,8 \%)$ represents. The EU base of respondents is 26.544 , of which 4.001 are V4 respondents. Czech Republic (83\%). It is higher than in Hungary $(70,7 \%)$ or Slovakia $(71,1 \%)$, but higher than the EU-28 average $(78,8 \%)$.

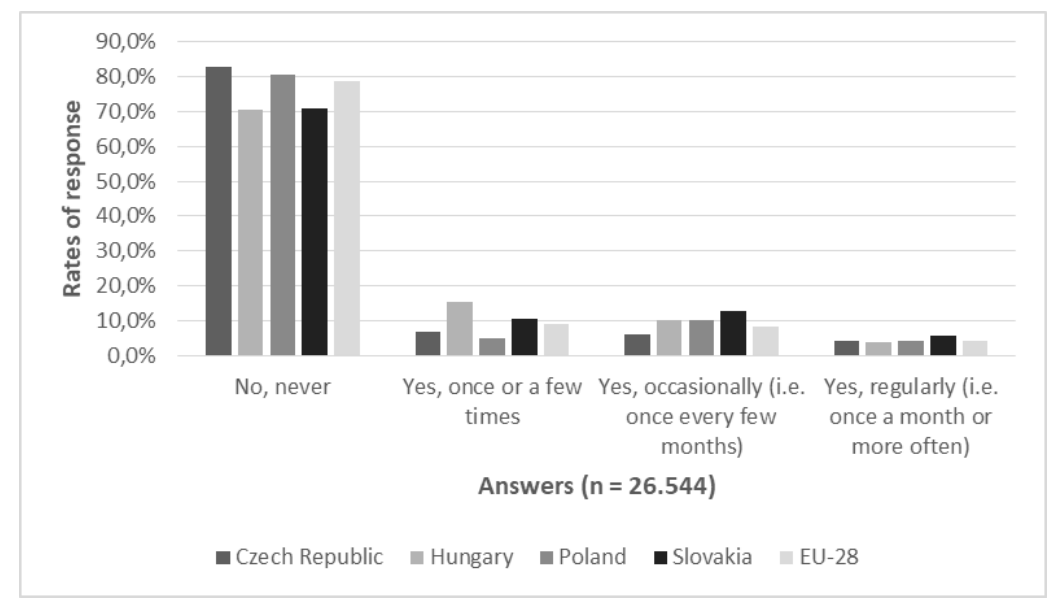

Figure 3. Proportion of Users of Services Offered via Collaborative Platforms Source: Authors' own editing 
In terms of the popularity of the services used, transport and accommodation sharing Internet platforms are the most popular among users (Figure 4). Transport services represent more than $60 \%$ of the Czechs and Polish, which is almost $80 \%$ above the EU-28 average. According to a study (European Commission, 2018) measuring the development of the Collaborative economy in the European Union, there are 7 in the Czech Republic (4 domestic, 3 international) and 8 in Hungary (5 domestic, 3 international), 9 in Poland (6 domestic, 3 international) and 3 in Slovakia an international transport platform provider.

Czech regulation clearly distinguishes between car sharing (e.g. Uber, Taxify / Bolt) and carpooling (e.g. BlaBlaCar, Oszkar), and while car sharing is regarded as a taxi service or an economic activity, it is not carpooling. In the fall of 2017, the Ministry of Transport announced its intention to amend the Road Transport Act to create the ability for online applications to operate within the regulatory framework.

In Hungary, for-profit ridesharing services cannot operate, and there are strict regulations governing the carriage of passengers: they are subject to licensing, the fares are prefixed, and the dynamic pricing is prohibited. These conditions disqualified Uber and decided to retire in the fall of 2016. Bolt and similar Internet delivery platforms / applications that are able to connect the service provider with the buyer are still operational, as their services are not considered similar to those of a licensed taxi service (European Commission, 2018)

Accommodation platforms are very popular in the V4, although this is slightly lower in Poland $(40,8 \%)$ and below the EU-28 average $(52,8 \%)$.

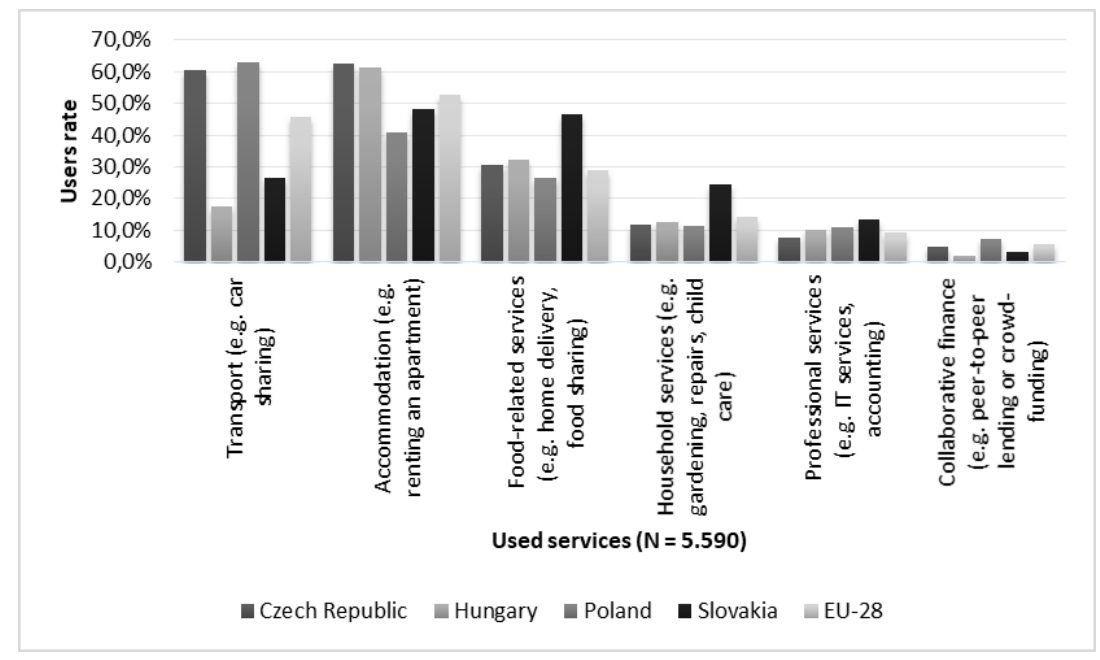

Figure 4. V4-EU-28: Popularity of Provided Services Offered via Collaborative Platforms Source: Authors' own editing

Respondents unanimously (around 70\%) highlighted convenient access to services as the main benefit of services offered through social platforms (Figure 5). In five out of the six options offered, Czech users achieved the highest rates in the Czech Republic, so overall they said they were positive about the benefits of the services they used. However, the praise of Hungarian users was remarkably narrow, and enthusiasm was rather extinguished. More than $80 \%$ of Czech users said that the services offered in this way were cheaper or free, with $72,2 \%$ highlighting the availability of user reviews, followed by a wide range of services $(64,5 \%)$. The least attractive feature of services offered through collaborative platforms is the ability to exchange services instead of fiction. 


\section{Issues in Information Systems}

Volume 21, Issue 1, pp. 153- 166, 2020

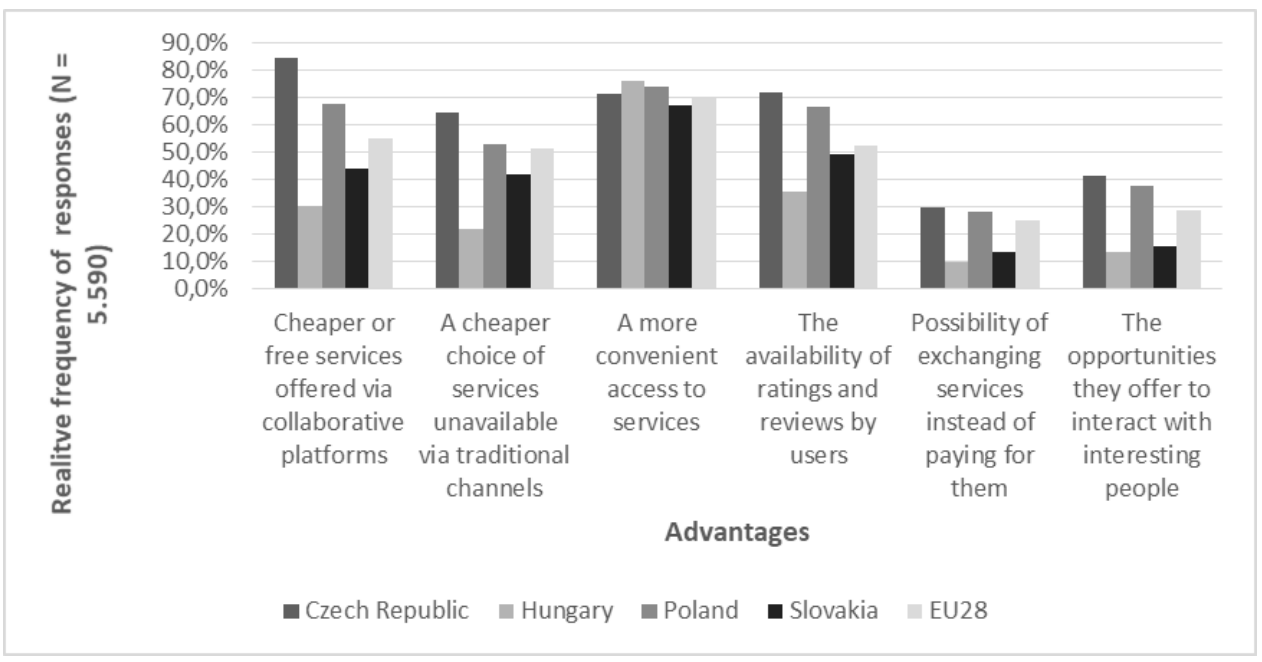

Figure 5. V4-EU28: Advantages of Services Offered via Collaborative Platforms Source: Authors' own editing

In terms of the experienced disadvantages, the EU-28 and V4 averages are roughly the same, and Slovak users totally same as EU average. Outstanding values can be seen in most cases in the Czech Republic (Figure 6): problems with the online booking process or payments $(19,5 \%)$, services offered via collaborative platforms are not as expected $(21,3 \%)$, less trust in providers of services offered via collaborative platforms $(43,8 \%)$ and lack clarity about who is responsible for the event of the problem $(55,6 \%)$. On the other hand, Hungarian users do not consider the services offered via platforms to be problematic $(43,7 \%)$. The opinion of Polish users shows a higher percentage in three cases compared to the EU-28 average, so they are concerned about the misuse of their personal data, the credibility of the ratings, and more than half uncertain who has the responsibility / obligation to resolve any service problems that may arise.

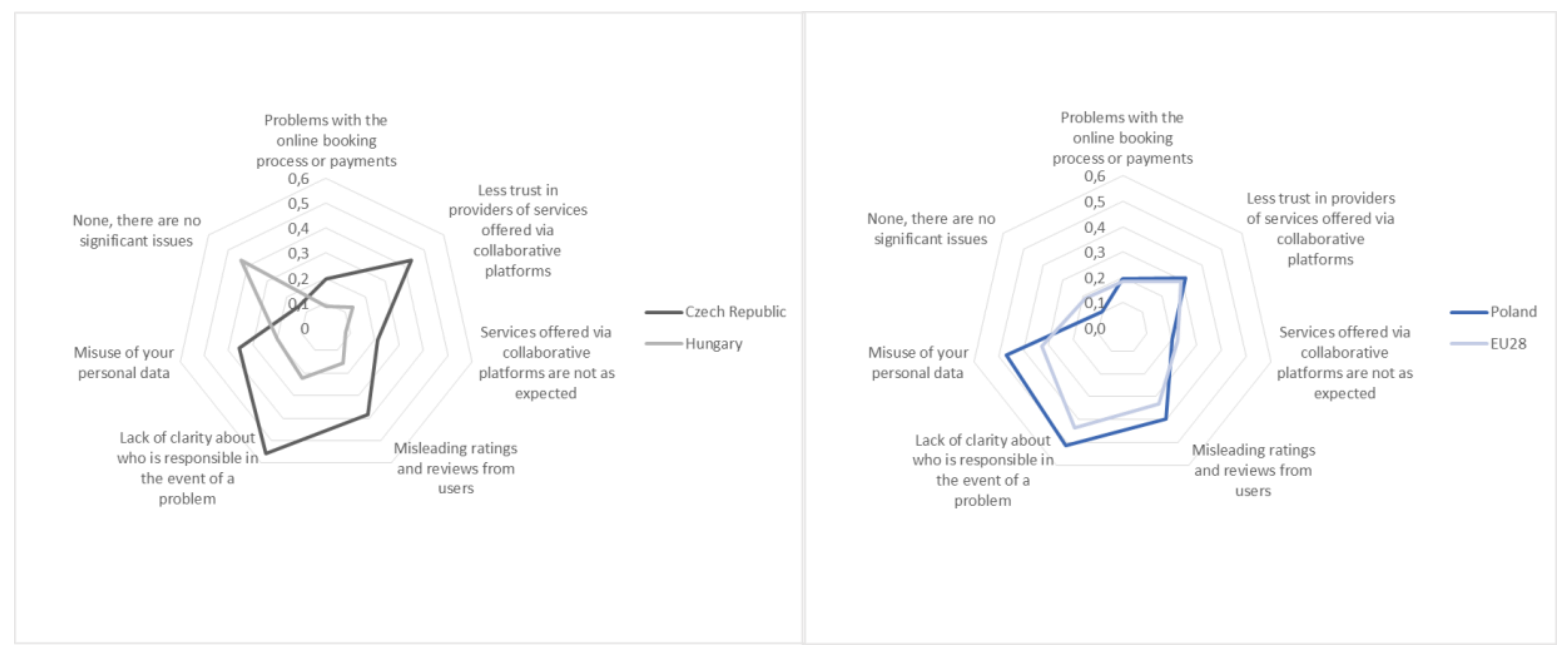

Figure 6. V4-EU-28: Disadvantages of services offered via collaborative platforms, $\mathrm{N}=5.590$

Source: Authors' own editing

The main reason for not using the platforms of the collaborative economy is the lack of awareness of the platforms and the lack of trust or bias in traditional trade channels (Figure 7). Poor Internet connectivity as a deterrent has been very low, both in the V4 countries and in the EU-28 average (up to 8\% in Poland). 


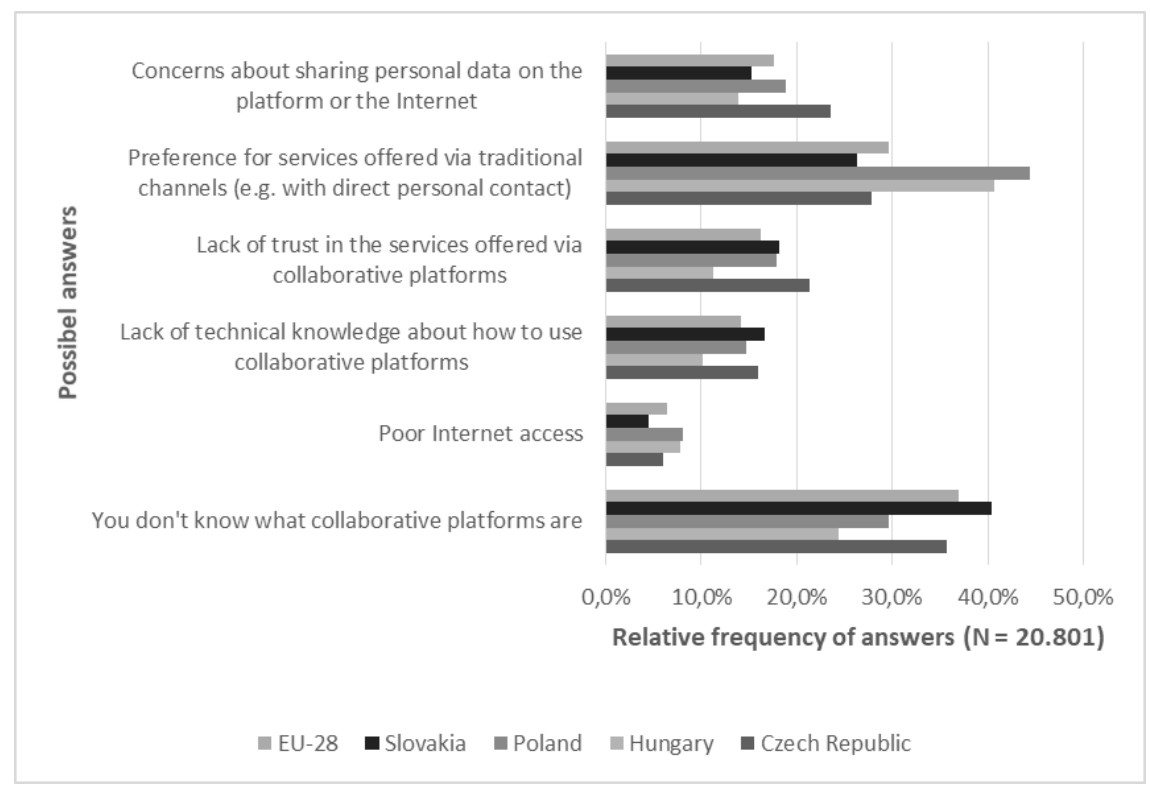

Figure 7. V4-EU-28: Reasons for not using services offered via collaborative platforms Source: Authors' own editing

\section{Provision of Services via Collaborative Platforms}

Approaching from the provider side it can be find that their rate is rather low, with more than $90 \%$ of survey participants not yet offering services through platforms (Table 2). The proportion of service providers is the highest in Slovakia and Hungary, while the share of Czech and Polish service providers is less than 5\%.

Table 2. V4 country: Percentage of service providers via collaborative platforms

\begin{tabular}{|c|c|c|c|c|c|c|}
\hline \multicolumn{7}{|c|}{$\begin{array}{l}\text { COUNTRY CODE - ISO } 3166 \text { * D9 USE OF COLLABORATIVE } \\
\text { PLATFORMS: AS A SERVICE PROVIDER Crosstabulation }\end{array}$} \\
\hline \multicolumn{7}{|c|}{ \% within COUNTRY CODE - ISO 3166} \\
\hline & & \multicolumn{4}{|c|}{ A SERVCE PROMDER } & \multirow[b]{2}{*}{ Total } \\
\hline & & No, never & $\begin{array}{c}\text { Yes, once } \\
\text { or a few } \\
\text { times }\end{array}$ & \begin{tabular}{|c|} 
Yes, \\
occasionally \\
(i.e. once \\
every few \\
months) \\
\end{tabular} & \begin{tabular}{|c|} 
Yes, \\
regularly (i.e. \\
once a \\
month or \\
more often) \\
\end{tabular} & \\
\hline $\begin{array}{l}\text { COUNTRY } \\
\text { CODE - ISO }\end{array}$ & $\begin{array}{l}\text { Czech } \\
\text { Republic }\end{array}$ & $95,8 \%$ & $1,9 \%$ & $1,0 \%$ & $1,3 \%$ & $100,0 \%$ \\
\hline \multirow[t]{3}{*}{3166} & Hungary & $93,2 \%$ & $4,7 \%$ & $1,3 \%$ & $0,8 \%$ & $100,0 \%$ \\
\hline & Poland & $95,2 \%$ & $2,1 \%$ & $1,9 \%$ & $0,8 \%$ & $100,0 \%$ \\
\hline & Slovakia & $91,2 \%$ & $4,2 \%$ & $3,5 \%$ & $1,1 \%$ & $100,0 \%$ \\
\hline Total & & $93,8 \%$ & $3,2 \%$ & $1,9 \%$ & $1,0 \%$ & $100,0 \%$ \\
\hline
\end{tabular}

In Slovakia, only 1, 6\% of survey respondents offered services via internet networking platforms, while in Hungary and Poland this proportion was 50\% lower. Only 1, 2\% of Czechs said they were involved in the collaborative economy as a service provider. Service providers in the collaborative economy are primarily active in transport and accommodation services. Poland (54, 2\%) and the Czech Republic (47, 6\%) have the highest rates of transport providers, well above the EU-28 average of 34\% (Figure 8). Hungary (27, 9\%) is the most popular accommodation service, which is still below the EU-28 and the Polish proportion. Slovaks have the highest share of household providers $(28,4 \%)$, followed by accommodation and car sharing. 


\section{Issues in Information Systems}

Volume 21, Issue 1, pp. 153- 166, 2020

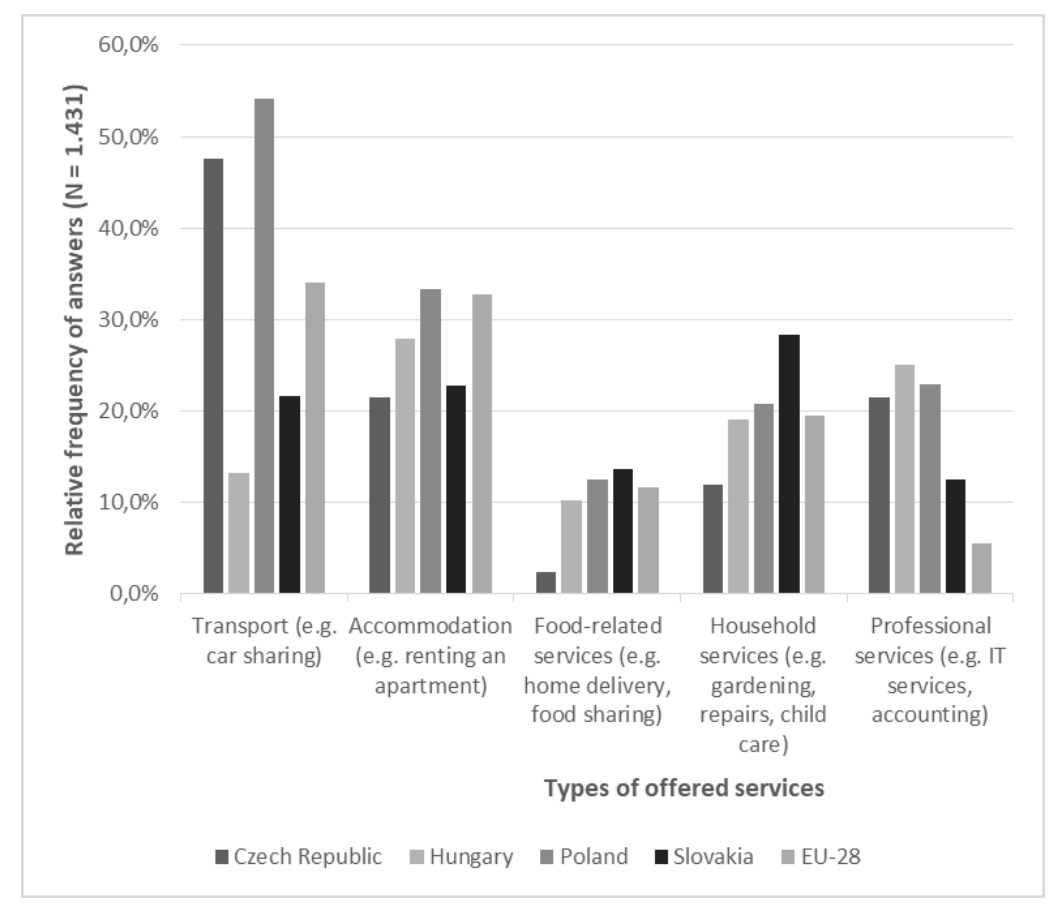

Figure 8. V4-EU-28: The most commonly offered services via collaborative platforms Source: Authors' own editing

The list of possible services also included collaborative finance, but we could not demonstrate a significant relationship between collaborative finance and individual V4 countries with Pearson's Chi-square statistical test due to the small number of items and could not be verified with Fisher's exact test significance, because the relationship was not supported. Service providers on platforms (Figure 9) have highlighted the following benefits for the collaborative economy:

- The $60 \%$ of Polish suppliers emphasize the more sustainable and efficient use of available assets and the easy opportunity to become a services provider. Only $12,5 \%$ see it as their main source of income, while $56 \%$ see it as an additional source of income.

- More than 50\% of Czech suppliers accentuate the easiest way to interact with consumers, just like the sustainable and efficient use of assets and the feature of additional income. Only $4,8 \%$ consider it as a revenue source for the main source of income, which is already the lowest rate in the V4 countries, and half of the EU-28 average as well.

- The Hungarian providers most of all underline the access to more consumers and the aspect of additional income, however, it is worth noting here that they are much more cautious about the potential benefits than other V4 states.

- The Slovak providers is also characterised by low praise. They rank first in income complementarity (56, $3 \%)$, followed by a large number of consumer outreach $(35,2 \%)$. 


\section{Issues in Information Systems}

Volume 21, Issue 1, pp. 153- 166, 2020

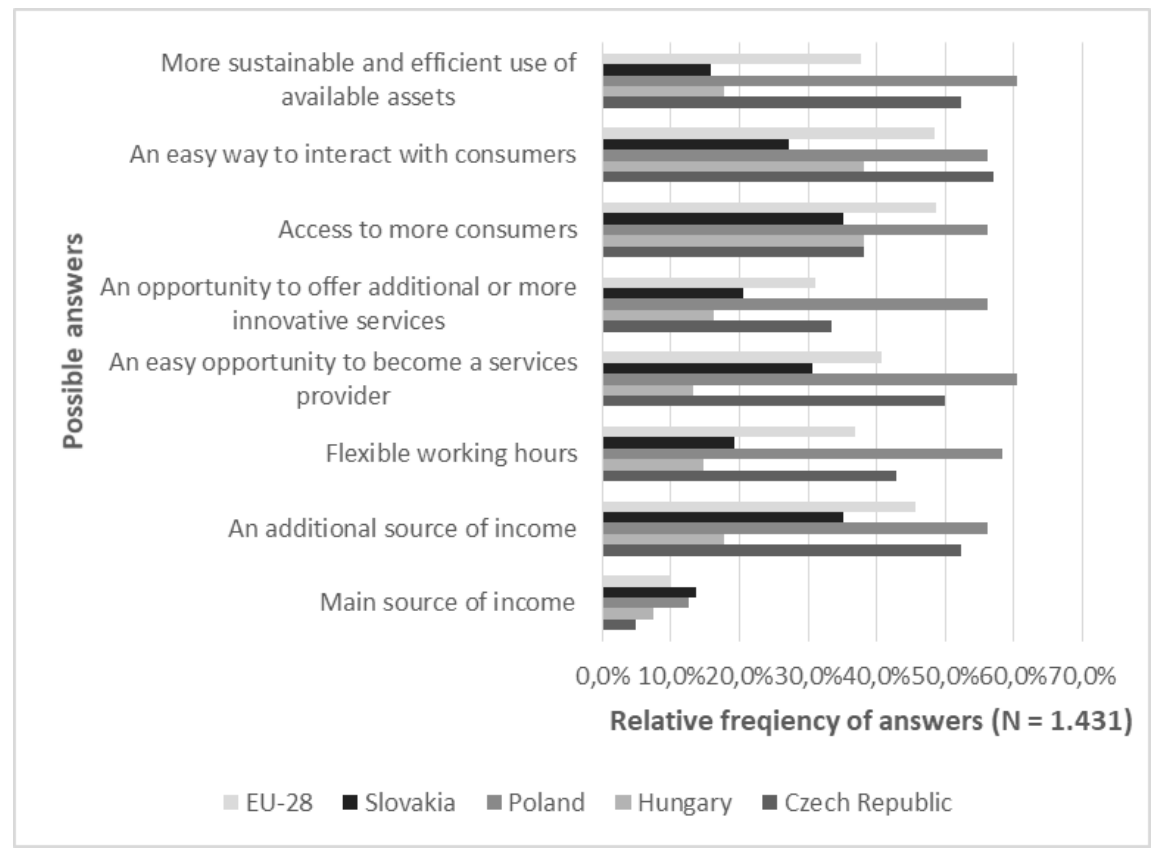

Figure 9. V4-EU-28: Reasons for offering services via collaborative platforms Source: Authors' own editing

The service providers almost unanimously claim that they do not experience any particular problems with the provision of the service and do not feel that it is cumbersome (Figure 10). Where problems do arise, however, this can be attributed to the lack of a legal framework as tax conditions and obligations (personal income tax, social security contributions, etc.) and responsibilities are not clarified. 37, 5\% of Polish, 27, 9\% of Hungarian and 19\% of Czechs service providers consider lack of legality to be an impediment.

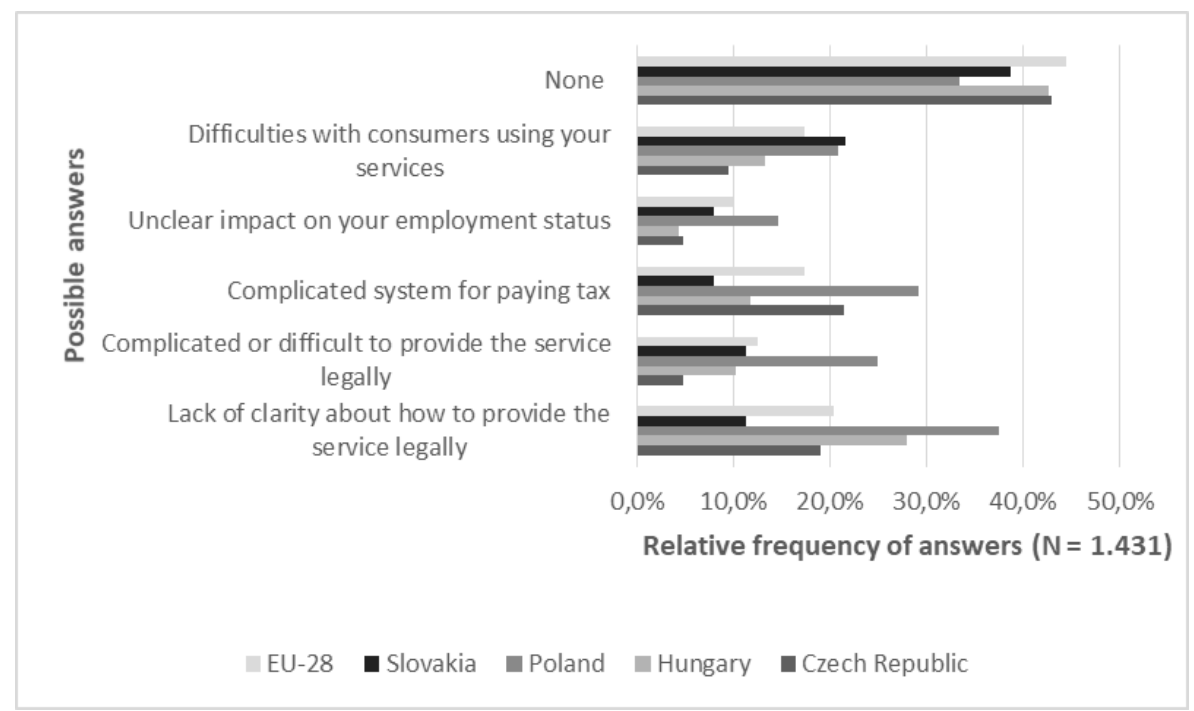

Figure 10. V4-EU-28: Main problems of service providers using collaborative platforms Source: Authors' own editing

The service provider side was on a small scale represented in this survey, and the most popular ones were the transport and accommodation services. The majority of service providers consider the provision of services through social platforms to be trouble-free, and overall their perception of the service modality is positive. Participants in the Polish and Czech service are much more enthusiastic, giving several reasons for their involvement in the collaborative economy as a service provider, but their criticism is high. In contrast, Hungarian 
service providers are much more moderate about the reasons for participation, and in return they do not stress the difficulties involved, except for regulatory gaps.

\section{LIMITATIONS}

During analysis we used the database ZA6937 Data file Version 1.0.0 for the European Commission, Brussels (2018): Flash Eurobarometer 467 to examine the awareness / spread of the collaborative economy. When analysing the data, we were confronted with the fact that the average age of the respondents was 53 , namely half of the respondents were over 53. In contrast, the median age of the EU population was 43, 1 years (Eurostat, 2019). The youngest interviewee is 15 years old and the oldest is 95 years old. The mean value in the sample is 60 (Figure 11), so most of the 60s are included in the sample. The standard deviation is 16, 67, which means that the values deviate from the average by 16,67 . Knowing all of this information, there is a probability that the results do not adequately reflect the age distribution of the EU population. In the collaborative economy, the two most active age groups are 25-34 and 35-44, respectively, according to JP Morgan's research (JP Morgan Chase\&Co, 2016), while in the available database, those over the age of 44 are nearly two thirds majority. The research should have taken into account the age groups relevant to the collaborative economy, which are 25-39 years (Y generation) and 40-55 years (X generation). Since these age groups are underrepresented in the sample, the evaluation of the survey was burdened with uncertainty.

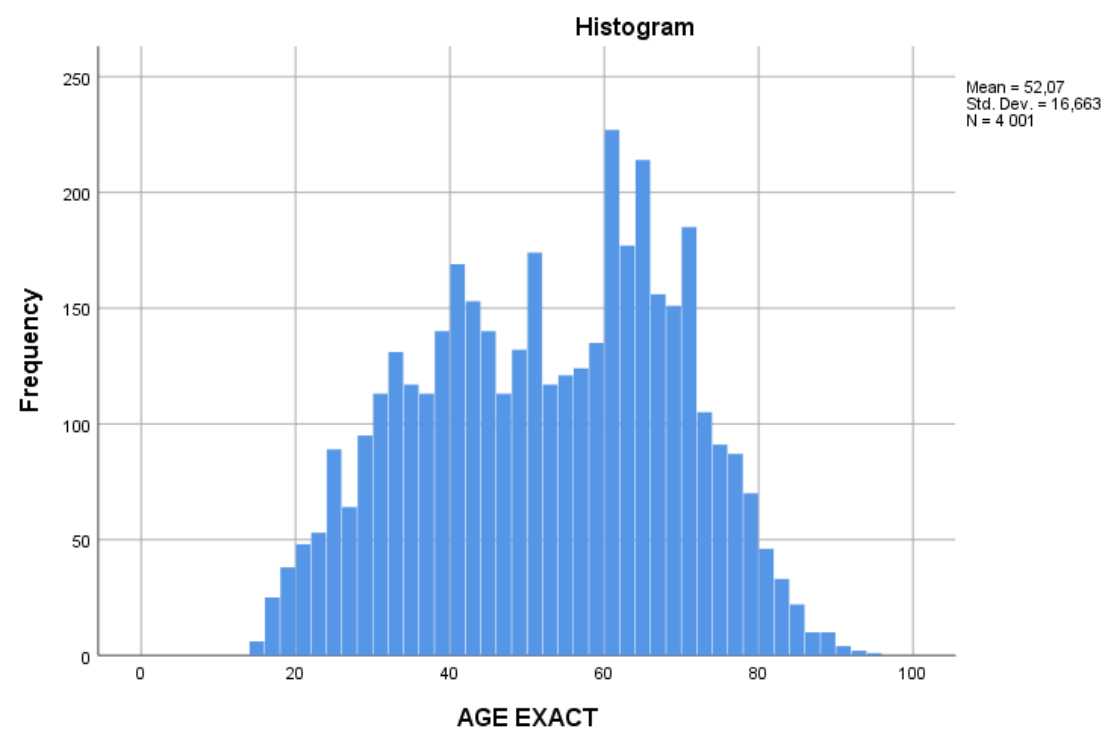

Figure 11. Age frequency of surveyed participants in V4 countries Source: Authors' own editing

\section{CONCLUSIONS}

The characteristic of Internet Platform Based Collaborative Economy has been defined based on the processing of numerous international literature and the analysis of the authors. The Collaborative Economy is a demanddriven economic activity run by technology companies in digital markets, where they meet consumers' needs through instant online access to goods and services via online platforms. In digital markets, information / goods related to products or services are provided by several third parties. The transactions are processed by the market operator (technology company). The business model is not only about renting, but about the re-use of unused assets through sales and the use of online marketplaces. The collaborative platform based economy distinguishes between the concepts of Collaborative Consumption (CC) and Sharing Economy (SE), which it defines as follows: CC - Demand-driven Internet platform based business model in which the service provider is a business and can operate in a redistribution market system or product service system. In a redistribution market system, the ownership of the good is transferred to the consumer after the transaction (sale), while the product service system allows only temporary access to the same good (leasing). Transactions can occur in B2B and B2P configurations. SE - Demand driven business platform based on an Internet platform where the service provider is a peer and can operate in a redistribution market system or product service system. In a redistribution market system, the 
ownership of the good is transferred to the consumer after the transaction (sale), while the product service system allows only temporary access to assets (renting). Transactions can occur in both $\mathrm{P} 2 \mathrm{P}$ and $\mathrm{P} 2 \mathrm{~B}$ configurations

The Internet platform-based collaborative economy has a history of just over a decade and its emergence is linked to the turbulent post-2008 era. For this reason, its awareness is very limited, as shown by the current survey, as the average $20 \%$ of respondents are familiar with the concept of collaborative economy. PwC's 2016 analysis shows that by 2025 the value of transactions in the collaborative economy could reach $€ 570$ billion, a 20 -fold increase from 2015 ( $€ 28$ billion) (PwC, 2016). Closely related to this is that regulatory deficiencies make it difficult to measure the number and value of transactions that actually occur (lack of clarity obligations) and, moreover, there is no consensus on what falls under the umbrella of the collaborative economy. PwC (2016) focused on collaborative finance, $\mathrm{p} 2 \mathrm{p}$ accommodation, $\mathrm{p} 2 \mathrm{p}$ transportation, on-demand household services and ondemand professional services. In our view, the internet platform based collaborative economy encompasses a much wider area and not only p2p transactions but also b2p, b2b and p2b transactions should be included here. Furthermore, not only platforms providing temporary access are considered to be part of the collaborative economy, but also the transfer of the ownership through Internet platforms (Kovács \& Nábrádi, 2020). Using the European Commission database for the V4 countries the following conclusions were drawn:

- Slovakia and Hungary are slightly more familiar with the concept of the collaborative economy (30\%), followed by Poland and the Czech Republic, where the proportion is around 20\%. Hungary has the highest proportion of service users and the Czechs are on the opposite side. The share of Slovaks participating in the service economy as a service provider is the highest and the share of Polish service providers is the lowest.

- The most popular services in the collaborative economy are accommodation and transport services. Obviously, demand and supply overlap, so if the greatest demand is for these services, the proportion of these providers is also highest on the supply side. Uber was banned in Hungary in 2016, and this is back in the survey, as the popularity of transport services here is far below the Czech or Polish popularity index.

- Dissecting the advantages and disadvantages of collaborative-based services offered on the Internet platform, we found that the Czechs list both the highest "positive and negative" criticisms at the same time. The Czechs ranked first $(\cong 80 \%)$ as a positive, the cheaper or free services offered via collaborative platforms and only $30 \%$ of Hungarian users considered it. Hungarian, Slovakian and Polish users indicate easy access to the services.

- In terms of disadvantages, the V4 average and the EU average are nearly the same. Of the Czech users, above half $(55,6 \%)$ see the lack of clarity about who is responsible for the problem as the biggest disadvantage, which is the highest among the V4. Other outliers are also seen among Czech users, who are distrustful of the credibility of consumer reviews $(38,5 \%)$ and of providers offering their services via collaborative platforms $(43,8 \%)$. In contrast, nearly $45 \%$ of Hungarian users did not have trouble in accessing services.

- The lack of knowledge was almost unanimously cited by users as the main reason for not using Internet-based collaborative platforms.

- The number of those involved in the collaborative economy as service providers is very limited. Most service providers were found in Slovakia $(8,8 \%)$ and the least in the Czech Republic (4, 2\%).

- Participants in the Polish and Czech service are much more enthusiastic, giving several reasons for their involvement in the collaborative economy as a service provider, but their criticism is high. In contrast, Hungarian service providers are much more moderate about the reasons for participation, and in return they do not stress the difficulties involved, except for regulatory gaps.

\section{FURTHER RESEARCH DIRECTION}

The collaborative platform based economy draws our attention to the power of cooperation. The renewed economic recession, which is likely to emerge, reinforces the fact that the collaborative economy can mitigate the effects of the crisis, but not only because of the income-generating nature of the activity. This is proved by the increased number of orders through the online delivery applications (such as Deliveroo, Just Eat, Uber Eats, Wolt, Takeaway.com, etc.), make an unprecedented number of small businesses request the help of citizens to ease this difficult period with their donations (crowdfunding). Initiatives have also appeared on online marketplaces where SMEs offer their services not only by searching for customers but also by helping each other (e.g. Stronger Together - Saving our businesses). Because of current uncertain situation new fields of collaborative economy come to the fore, e.g. personal and professional services, online contents or finance.

The prevailing crisis and economic recession point out that it is not an opportunity, but a necessity, to analyse the subject in greater depth. 10 years have passed but international regulation of the platform based collaborative economy have not happened. There is no unanimous opinion on what is meant by which areas. We believe that 
our Platform-based Collaborative Economy definition without overlapping can help to maintain a clear vision and better regulation for the survival of small and medium-sized enterprises. However, this requires a detailed economic analysis.

\section{ACKNOWLEDGEMENTS}

This paper is supported by EFOP-3.6.3-VEKOP-16-2017-00007 - „Young researchers for talent” - supporting careers in research activities in higher education program.

\section{BIBLIOGRAPHY}

Belk, R. (2014). You are what you can access: Sharing and collaborative consumption online. Journal of Business Research, 1595-1600. Letöltés dátuma: 2019. 02 20, forrás: https://collaborativeeconomy.com/wp/wpcontent/uploads/2015/05/Belk-R.2014.-You-are-what-you-can-access-Sharing-and-collaborativeconsumption-online.Journal-of-Business-Research.pdf

Botsman, R., \& Rogers, R. (2010). What's Mine Is Yours: The Rise of Collaborative Consumption. New York: Harper Business.

CBInsights. (2020. 01 16). cbisights.com. Forrás: The Global Unicorn Club: https://www.cbinsights.com/reports/CB-Insights_Global-Unicorn-Club_2019.xlsx

Codagnone, C., Biagi, F., \& Abadie, F. (2016). The Passions and the Interests: Unpacking the 'Sharing Economy'. Institute for Prospective Technological Studies. Seville: JRC Science for Policy Report EUR 27914 EN. doi:10.2791/474555

Dajnoki, K., \& Héder, M. (2017). „Új szelek fújnak” - a HR válasza a globalizáció és a változás kihívásaira [„,New Winds Blow" - The Answer of HR for the Challenges of Globalization and the Change]. Hadtudomány, 84-93. doi:10.17047/HADTUD.2017.27.E.84

European Commission. (2016). A European agenda for the collaborative economy. Brussels: European Commission. Letöltés dátuma: 2019. 0106

European Commission. (2018). Flash Eurobarometer 467 (The Use of Collaborative Economy). GESIS Data Archive, Cologne. Brussels: TNS opinion . doi:https://doi.org/10.4232/1.13159

European Commission. (2018). Study to Monitor the Economic Development of the Collaborative Economy in the $E U$. Luxembourg: Publications Office of the European Union.

Eurostat. (2019). Ageing Europe. Luxembourg: European Union. doi:10.2785/811048

Feiner, L. (2019. 05 10). Uber ends its first day of trading down more than 7\%. Letöltés dátuma: 2019. 09 15, forrás: CNBC: https://www.cnbc.com/2019/05/10/uber-ipo-stock-starts-trading-on-the-new-york-stockexchange.html

Gansky, L. (2010). The Mesh. Why the future of business is sharing. New York, USA: Penguin Group Inc.

Héder, M., Szabó, S., \& Dajnoki, K. (2018). Effect of labour market changes on HR functions. Anali Ekonomskog fakulteta u Subotici(39), 123-138. doi:10.5937/AnEkSub1839123H

Heinrichs, H. (2013). Sharing Economy: A Potential New Pathway to Sustainability. Gaia(22(4)), 228-231.

Hurun Research Institute. (2019. 10 21). Hurun Report. Letöltés dátuma: 2020. 02 07, forrás: Hurun Global Unicorn List 2019: https://www.hurun.net/EN/Article/Details?num=A38B8285034B

Jaconi, M. (2014. 07 13). The 'On-Demand Economy' Is Revolutionizing Consumer Behavior - Here's How. Letöltés dátuma: 2020. 03 12, forrás: Business Insider: https://www.businessinsider.com/the-ondemand-economy-2014-7 
JP Morgan Chase\&Co. (2016). The Online Platform Economy. New York: JPMorgan Chase Institute. Forrás: https://www.jpmorganchase.com/corporate/institute/document/jpmc-institute-online-platform-econbrief.pdf

Kovács, T., \& Nábrádi, A. (2020). Types of platform based economy and its potential in agribusiness. (M. Jeločnik, Ed.) Western Balkan Journal of Agricultural Economics and Rural Develeopment, 2(1), In press.

Kovács, T., \& Nábrádi, A. (2020). Types of sharing economies and collaborative consumptions. In G. Druzic, \& T. Gelo (Ed.), Book of Abstracts of Internation Conference on Economics of Decoupling (ICED) Faculty of Economics \& Business (pp. In press (64-65)). Zagreb: Faculty of Economics \& Business, University of Zagreb. Retrieved from https://rive.google.com/file/d/1WMfW209MjLV6TBbZI77vqYWbaNWiy2-u/view

Kumar, V., Lahiri, A., \& Dogan, O. (2018). A strategic framework for a profitable business model is the sharing economy. Industrial Marketing Management, 69, 147-160. doi:10.1016/j.indmarman.2017.08.021

Martin, C., Upham, P., \& Budd, L. (2015. Október). Commercial orientation and grassroots social innovation: insight from the sharing economy. Ecological Economics(118), 240-251.

Miller, D. (2019. 06 25). The Balance SMB. Letöltés dátuma: 2020. 02 08, forrás: The Balance Small Business: https://www.thebalancesmb.com/the-sharing-economy-and-how-it-changes-industries-4172234

OCU. (2016). Collaboration or Business?. Collaborative Consumption: From value for users to a society with values. OCU Ediciones SA. Letöltés dátuma: 2020. $02 \quad 08$, forrás: https://www.oneplanetnetwork.org/sites/default/files/collaboration_or_business_cc_p2p_2016.pdf

PwC. (2015). Sharing or paring? Growth of the sharing economy. Hungary: PriceWaterhouseCoopers $\begin{array}{llllll}\text { Magyarország Kft. } \quad \text { Letöltés } & \text { dátuma: } 2020 . & 08, & \text { forrás: }\end{array}$ https://www.pwc.com/hu/en/kiadvanyok/assets/pdf/sharing-economy-en.pdf

PwC. (2016). The sharing economy presents Europe with a $€ 570$ billion opportunity. Budapest: PwC Hungary. Letöltés dátuma: $2020 . \quad 02 \quad 04, \quad$ forrás: https://www.pwc.com/hu/en/pressroom/2016/sharing_economy_europe.html

Schor, J. (2014. 10). Debating the Sharing Economy. Great Transition Initiative. Forrás: https://www.greattransition.org/publication/debating-the-sharing-economy

Schor, J., \& Fitzmaurice, C. (2015). Collaborating and Connecting: The emergence of the sharing economy. In L. Reisch, \& J. Thogersen, Handbook of Research on Sustainable Consumption (old.: 480). Cheltenham: Edward Elgar. doi:10.4337/9781783471270

Stephany, A. (2015). The Business of Sharing: Making it in the New Sharing Economy. London: Palgrave Macmillan UK.

Sundararajan, A. (2016). The Sharing Economy: The End of Employment and the Rise of Crowd-Base Capitalism. London: MIT Press. doi:ISBN: 9780262034579

Szegedi, L. (2019. 02 15). Digitális platformok mint a sharing economy munkáltatói? [Digital platforms as employers in sharing economy]. Letöltés dátuma: 2019. 05 23, forrás: arsboni.hu: https://arsboni.hu/digitalis-platformok-mint-a-sharing-economy-munkaltatoi/

Wallenstein, J., \& Shelat, U. (2017. 08 22). Hopping Aboard the Sharing Economy. Letöltés dátuma: 2020.0207, forrás: BCG Henderson Institute: https://www.bcg.com/en-us/publications/2017/strategy-acceleratinggrowth-consumer-products-hopping-aboard-sharing-economy.aspx 